\title{
Jaundice due to iprindole
}

\author{
A. B. AJDUKIEWICZ, J. GRAINGER, P. J. SCHEUER, AND S. SHERLOCK
}

From the Departments of Medicine and Pathology, Royal Free Hospital, London

SUMMARY Twenty-one patients treated for depression with iprindole developed evidence of liver damage: 15 were jaundiced, five had bilirubinuria, and one had pruritus. These complications occurred between four and 21 days after initial exposure to the drug. All patients recovered. Light and electron microscopic findings in liver biopsies of one of these patients were those of cholestasis without inflammation.

Antidepressants are among the most commonly prescribed drugs. Approximately $15 \%$ of all prescriptions written in Britain in recent years have been for psychotropic drugs (Dunlop, 1969). Iprindole (Prondol) was introduced in the early 1960s and is a commonly used antidepressant which is claimed to have few side effects. The two patients to be reported in detail were both treated with iprindole for depression and developed a hepatic reaction; in one of these, liver biopsies were taken for light and electron microscopy. In addition, the clinical features in 19 other patients who had a hepatic reaction to iprindole are described.

\section{Case Reports}

CASE 1

A 36-year-old woman had been unwell for two years. She has four children aged 15,13, 8, and 6 years, and in February 1969 was sterilized after a deep venous thrombosis while taking oral contraceptives. The family live in a tied cottage on a farm. In July 1969 she was feeling depressed and was treated with iprindole $15 \mathrm{mg}$ three times daily. One week later Received for publication 24 June 1971. she developed headache, fever, giddiness, and sweating, and three days later she noticed that her eyes were yellow and so stopped the iprindole. There had been no nausea, vomiting, or abdominal pain. The jaundice persisted and was associated with pruritus, dark urine, and pale stools. She had had no blood transfusions, no other drugs, and no contact with a jaundiced person. Alcohol intake had been minimal. Two months after starting iprindole she was admitted to hospital. Apart from jaundice the examination was unremarkable. The jaundice persisted and 12 weeks after the onset she was transferred to the Royal Free Hospital.

On examination she was jaundiced and there were scratch marks over the trunk. The liver edge was soft, slightly tender, and just palpable. Investigations showed a normal white blood cell count, eosinophil count, serum albumin and serum globulin. Hepatitis-associated antigen was not found in the serum. Results of liver function tests are shown in the Table.

Itching was controlled using cholestyramine. She improved so that five months after starting the iprindole she was well and physical examination was normal.

\begin{tabular}{|c|c|c|c|c|c|c|c|c|}
\hline $\begin{array}{l}\text { Case } \\
\text { No. }\end{array}$ & Sex & Age & $\begin{array}{l}\text { Time }(w k) \text { since } \\
\text { Starting Iprindole }\end{array}$ & $\begin{array}{l}\text { Bilirubin Total } \\
(0.3-1.0 \mathrm{mg} / 100 \mathrm{ml})\end{array}$ & $\begin{array}{l}\text { Bilirubin } \\
\text { Conjugated } \\
(0.5 \mathrm{mg} / 100 \mathrm{ml})\end{array}$ & $\begin{array}{l}\text { Alkaline } \\
\text { Phosphatase } \\
\text { (3-13 KA units) }\end{array}$ & $\begin{array}{l}\text { Aspartate } \\
\text { Transaminase } \\
(5-17 \text { iu/l) }\end{array}$ & $\begin{array}{l}\text { Cholesterol } \\
(130-260 \mathrm{mg} / 100 \mathrm{ml})\end{array}$ \\
\hline 1 & $\mathbf{F}$ & 36 & $\begin{array}{r}8 \\
12 \\
20\end{array}$ & $\begin{array}{l}7 \cdot 6 \\
7 \cdot 8 \\
0 \cdot 6\end{array}$ & $\begin{array}{l}7 \cdot 0 \\
0.5\end{array}$ & $\begin{array}{r}13 \\
16 \\
8\end{array}$ & $\begin{array}{r}80 \\
48 \\
8\end{array}$ & $\begin{array}{l}220 \\
270 \\
180\end{array}$ \\
\hline 2 & $\mathbf{M}$ & 48 & $\begin{array}{l}1 \\
5\end{array}$ & $\begin{array}{l}2 \cdot 7 \\
1.2\end{array}$ & $\overline{0.6}$ & $\begin{array}{l}21 \\
11\end{array}$ & $\begin{array}{r}40 \\
6\end{array}$ & - \\
\hline
\end{tabular}

Table Serum changes in two patients 
CASE 2

A travel agent aged 48 years had been receiving psychiatric treatment since his divorce six years ago. He was treated with chlordiazopoxide until two years ago. In 1943 he had suffered from infective hepatitis while in West Africa. Alcohol intake had been moderate. In May 1969 iprindole $30 \mathrm{mg}$ three times a day had been prescribed. One week later he passed dark urine, lost his appetite, was febrile, felt tired, and developed an ache over the liver. His most troublesome complaint was itching. Examination showed no abnormality apart from slight jaundice. His urine contained bilirubin and excess urobilinogen. The white blood cell count was $5,100 / \mathrm{cmm}$ and there was no eosinophilia. Liver function tests are shown in the Table. He stopped taking iprindole at the onset of his symptoms and gradually recovered over a period of five weeks.

\section{Clinical Summary of 19 Cases}

Records made available for study by the Committee on Safety of Drugs disclosed 19 patients who showed features suggestive of liver damage related to the ingestion of iprindole. Sixteen were female and three male and they were between 22 and 66 years of age. In all the symptoms developed between four and 21 days after commencing the drug. Jaundice was noticed in 13 of these patients, and five of the others had bilirubinuria. The 19th patient had pruritus which disappeared on stopping the drug, and reappeared on rechallenge. A rash was not present in this patient. Two of the jaundiced patients also complained of pruritus. Fever, shivering, generalized aches and pains, or an influenza-like illness were mentioned in six. In four these symptoms preceded the onset of jaundice. Three patients had a rash and one was found to have an eosinophilia. Liver biopsy was not performed on any of these patients. They all recovered.

\section{Hepatic Histology in Case 1}

The first biopsy, taken 12 weeks after the onset of jaundice, showed severe cholestasis, most marked at the centres of the lobules. No inflammatory reaction was seen either in the lobules or in the portal areas and there was no increase in tissue eosinophils. Increase in liver cell and nuclear size was noted particularly, and there were many binucleate cells. The appearances were compatible with druginduced cholestasis (Fig. 1).

The second biopsy, taken eight weeks later, showed that cholestasis was still present but less. The liver-cell swelling and nuclear abnormalities were no longer seen.

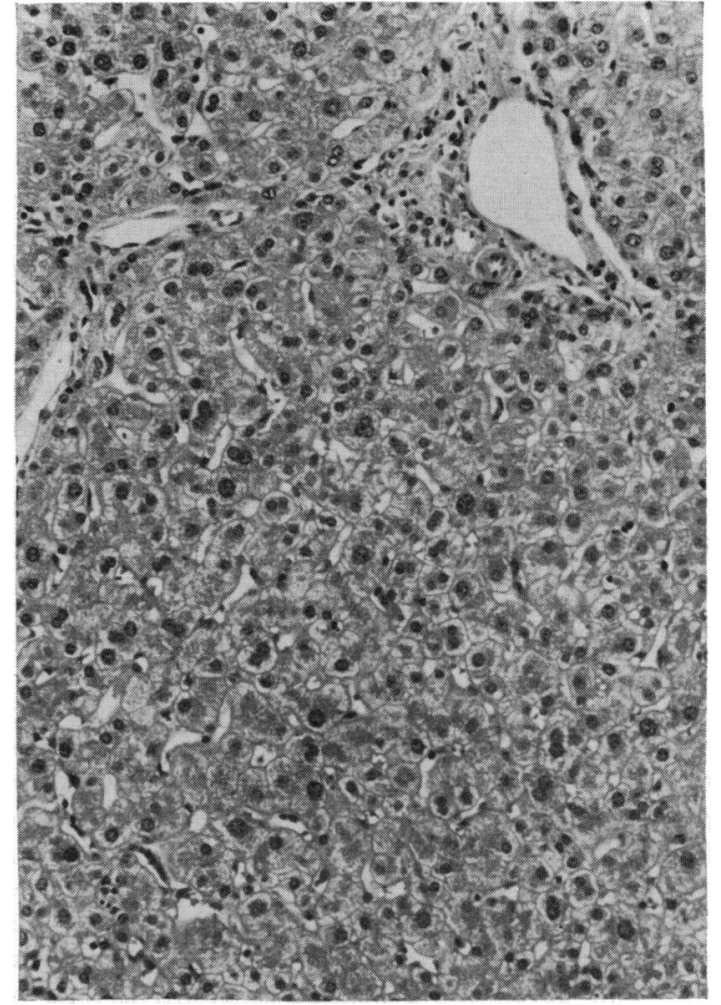

Fig. 1 Part of biopsy 1 with a normal portal tract on the left. Liver cell nuclei in the central part of the lobule $($ right $)$ are enlarged. Haematoxylin and eosin $(\times 150)$.

\section{Electron Microscopy in Case 1}

The ultrastructural changes in these two biopsies were those of cholestasis, as described by Steiner, Jézéquel, Phillips, Miyai, and Arakawa (1965) and Popper and Schaffner (1970). In the first biopsy the prominent ultrastructural feature was dilatation of bile canaliculi, and the presence in the lumens of osmiophilic deposits (Fig. 2). These densities corresponded to bile pigment as seen by the light microscope. In the second biopsy, canalicular dilatation was no longer present but occasional dense osmiophilic deposits were seen which were thought to represent remaining intracellular bile.

\section{Discussion}

Iprindole is a drug belonging to the iminodibenzyl class, and acts on the presynaptic adrenergic nerve endings. It is unusual among antidepressant drugs 


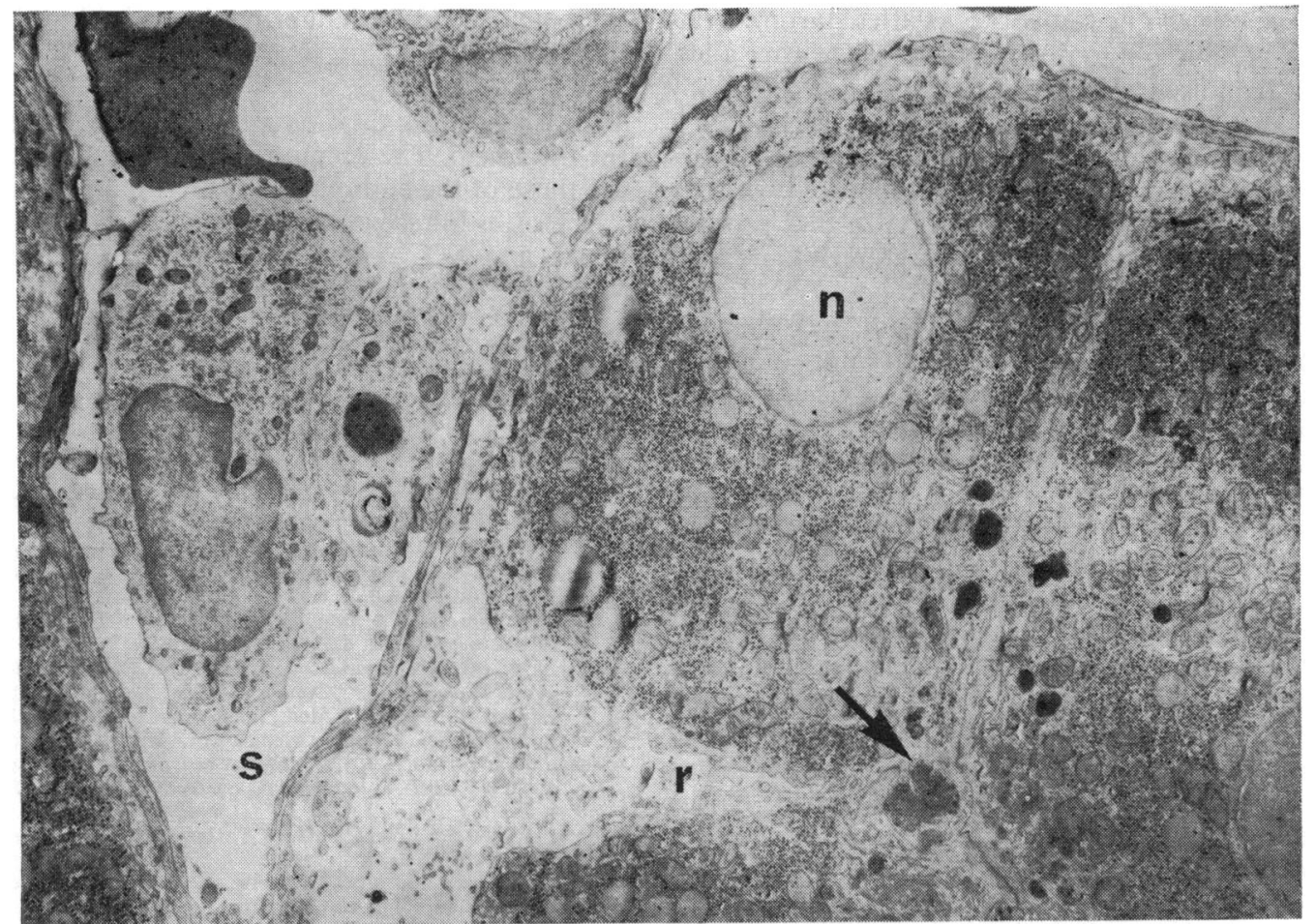

Fig. 2 Electron photomicrograph of centrilobular area from biopsy 1. A bile canaliculus (arrow) is dilated and contains a bile thrombus. The perisinusoidal recess $(r)$ extends from the sinusoids $(s)$. $n=$ liver cell nucleus. Fixed in osmic acid, embedded in Epon 812 and stained with lead citrate $(\times 4000)$.

in having an indole ring. During initial trials no evidence of hepatotoxicity was found (Hicks, 1965; Daneman, 1967) although relatively few patients were treated and fewer still had serial biochemical tests of liver function. Johnson and Maden (1967) mention one patient whose bilirubin level rose to $1.8 \mathrm{mg} / 100 \mathrm{ml}$ during the second week of treatment and was accompanied by eosinophilia. This patient had also received parenteral chlorpromazine just before the iprindole. Imlah (1968) treated eight female patients for one year and found no change in the bilirubin, alkaline phosphatase, or transaminase levels.

Young (1970) reported a 42-year-old woman who developed a generalized rash after taking five tablets of iprindole. This was associated with giant urticaria, dermatographia, and weal formation. She stopped taking the tablets and the rash cleared; on restarting, however, the rash recurred, she vomited bile-stained fluid, and felt ill. Her urine contained bilirubin. Serum bilirubin was $1.3 \mathrm{mg} / 100 \mathrm{ml}$, alkaline phosphatase 25 KA units, and GP transaminase 120 units. After finally stopping the tablets she recovered.
Price and Collings-Wells (1970) reported two further patients. A 30-year-old housewife was treated with iprindole for depression. A week later she felt unwell and 10 days after starting therapy became jaundiced and developed discomfort in the right hypochondrium. Serum bilirubin was $1 \cdot 1 \mathrm{mg} /$ $100 \mathrm{ml}$, alkaline phosphatase $10 \mathrm{KA}$ units, and alanine transaminase $60 \mathrm{iu}$. The drug was stopped and she made a complete recovery. The second patient was a 49-year-old man. Ten days after starting therapy he became ill with fever and malaise. Three days later he was jaundiced. Serum bilirubin was $1.8 \mathrm{mg} / 100 \mathrm{ml}$, alkaline phosphatase $19 \mathrm{KA}$ units and alanine transaminase $17 \mathrm{iu}$. Iprindole was discontinued and the patient gradually recovered.

Harrison and Stanley (1970) reported four female patients, three of whom had an influenza-like illness. Two patients developed jaundice and the third had slightly elevated transaminase levels. They all recovered following withdrawal of the iprindole.

The course of the illness in the three patients already reported and the 21 patients in the present report show certain similarities. The patients usually 
became unwell one to two weeks after starting treatment, although in some symptoms began after a few days. Jaundice followed the systemic upset and many experienced an ache over the liver. Pruritus, if present, was not usually severe. When iprindole was stopped, all symptoms usually disappeared within a few days. Case 1 was an exception in that pruritus lasted for 10 weeks and was severe enough to warrant cholestyramine therapy.

The two cases reported in detail, and many of those reported to the Committee on Safety of Drugs, presented clinically a predominantly cholestatic picture with jaundice and pruritus, as well as slightly elevated alkaline phosphatase levels in cases 1 and 2 . Evidence of hepatocellular damage was present in that aspartate transaminase levels were slightly elevated. The liver biopsy in case 1 showed cholestasis but no inflammation or necrosis. A generalized sensitivity reaction was suggested in the case reported by Young (1970) in that his patient had associated urticaria, dermatographia, and weal formation. However, in only two of all our cases was a rash present. One patient had an eosinophilia. It seems that iprindole may cause either a generalized hypersensitivity reaction with liver involvement or damage may be confined to the liver.

Jaundice has so far occurred in a very small minority of patients on the drug and in some the jaundice has been accompanied by other manifestations of hypersensitivity such as eosinophilia and dermatographia. When drugs of this type are tested in normal subjects no liver lesions are produced, and clinical trials must be extensive before a reaction is attributable with certainty to the drug. There is at present no evidence that iprindole can lead to chronic liver damage.

We wish to thank the Committee on Safety of Drugs for their help. The opinions expressed in this paper are those of the authors and not of that Committee.

A.B.A. is in receipt of a fellowship from the Davis Fund, and J.G. is supported by a grant from the Wellcome Foundation.

\section{References}

Daneman, E. A. (1967). Treatment of depressed patients with iprindole. Psychosomatics, 8, 216-221.

Dunlop, D. M. (1969). Drug control and the British Health Service. Ann. intern. Med., 71, 237-244.

Harrison, D. F., and Stanley, I. M. (1970). Allergy to iprindole (Prondol) with hepatotoxicity. Brit. med. J., 4, 368-369.

Hicks, J. T. (1965). Iprindole, a new antidepressant for use in general office practice. A double blind, placebo-controlled study. Illinois med. J., 128, 622-626.

Imlah, N. W. (1968). Experiences with WY3263. In Proceedings, 4th World Congress of Psychiatry, Madrid, 1966, edited by J. J. López Ibor (Excerpta Med. Int. Congr. Ser., no. 150), pt 4, pp. 2293-2296. Excerpta Medica Foundation, Amsterdam.

Johnson, J., and Maden, J. G. (1967). A new antidepressant-pramindole (WY 3263), a double-blind controlled trial. Clin. Trials J., 4, 787-791.

Popper, H., and Schaffner, F. (1970). Pathophysiology of cholestasis. Hum. Path., 1, 1-24.

Price, J. C. N., and Collings-Wells, J. A. (1970). Allergy to iprindole (Prondol) with hepatotoxicity. Brit. med. J., 1, 238239.

Rowden, G. (1969). A method of obtaining stained electron-microscope specimens free from contamination. J. Micr., 89, 229231.

Steiner, J. W., Jezzéquel A. M., Phillips, M. J., Miyai, K., and Arakawa, K. (1965). Extrahepatic cholestasis. In Progress in Liver Diseases, vol. II, edited by H. Popper and F. Schaffner, pp. 312-321. Grune and Stratton, New York and London.

Young, P. J. W. (1970). Allergy to iprindole (Prondol) with hepatotoxicity. Brit. med. J., 1, 367. 